\title{
Gilvusmycin, a New Antitumor Antibiotic Related to CC-1065
}

\author{
Yusuke Tokoro, Toshiyuki IsOe and Kazutoshi SHINDO* \\ Pharmaceutical Research Laboratory, Kirin Brewery Co., Ltd., \\ 3 Miyahara-cho, Takasaki-shi, Gunma 370-1295, Japan \\ (Received for publication December 18, 1998)
}

\begin{abstract}
A new antitumor antibiotic gilvusmycin was isolated from the culture broth of Streptomyces sp. QM16. The structure of gilvusmycin was related to CC-1065 and determined by NMR spectral analysis. Gilvusmycin exhibited antitumor activity against murine leukemia P388 in vivo.
\end{abstract}

In the course of screening for new antitumor antibiotics, Streptomyces sp. QM16 was found to produce a novel antitumor antibiotic gilvusmycin (1). 1 was recovered from both mycelium and filtered broth by extraction and purified by chromatography. Structural studies revealed it to possess similarity to $\mathrm{CC}-1065^{11}$ (2) (Fig. 1).

1 showed growth inhibition against various tumor cells in vitro, and also showed antitumor activity against murine leukemia $\mathrm{P} 388$ in vivo.

In this paper, we describe the production, isolation, structural elucidation and biological properties of $\mathbf{1}$.

Taxonomy of the Producing Strain

Culture QM16 was isolated from a soil sample collected at Takahashi, Okayama Prefecture, Japan. Characterization of the strain was carried out mainly by the methods described by SHIRLING and GotTLIEB ${ }^{2)}$. The aerial mycelium of the strain monopodially branched on the main stem and terminated in spirals forming spore chains with more than 50 spores per chain. The spores were cylindrical $(0.5 \sim 0.6 \times 0.7 \sim 1.0 \mu \mathrm{m})$ with smooth surfaces. The cultural and physiological properties of strain QM16 grown on various media at $27^{\circ} \mathrm{C}$ are shown in Tables 1 and 2, respectively. The whole-cell hydrolysate contained the $\mathrm{L}, \mathrm{L}$ isomer of diaminopimelic acid which corresponds to cell-wall type 1. Based on these morphological and chemotaxonomic characteristics, it was concluded that the strain belongs to the genus Streptomyces.

\section{Fermentation}

A well grown agar slant of Streptomyces sp. QM16 was used to inoculate a 500-ml Erlenmeyer flask con-

Fig. 1. Structure of gilvusmycin (1) and CC-1065 (2).

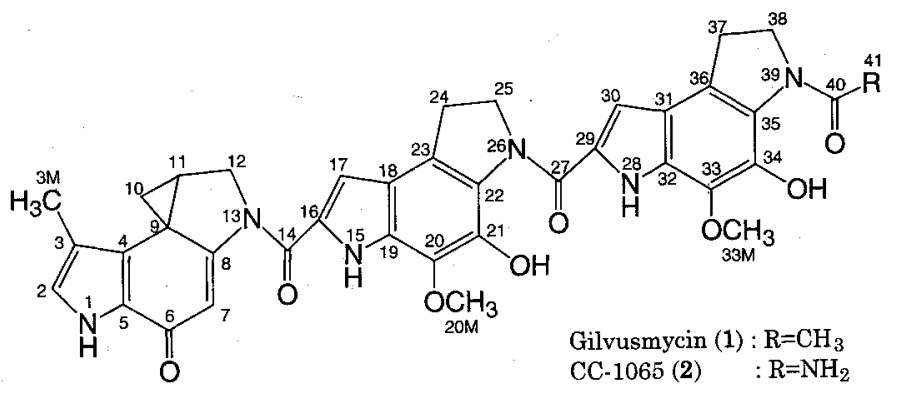


Table 1. Cultural characteristics of strain QM16.

\begin{tabular}{|c|c|c|c|}
\hline Sucrose-nitrate agar & $\mathrm{G}:$ & $\begin{array}{l}\text { Good } \\
\text { Am: } \\
\text { R: } \\
\text { Sp: }\end{array}$ & $\begin{array}{l}\text { Good; Yellowish gray } \\
\text { Pale yellowish brown } \\
\text { None }\end{array}$ \\
\hline $\begin{array}{l}\text { Glycerol-asparagine } \\
\text { agar }\end{array}$ & $\mathrm{G}:$ & $\begin{array}{l}\text { Good } \\
\text { Am: } \\
\text { R: } \\
\text { Sp: }\end{array}$ & $\begin{array}{l}\text { Good; Yellowish gray } \\
\text { Deep red } \\
\text { None }\end{array}$ \\
\hline $\begin{array}{l}\text { Yeast extract - malt } \\
\text { extract agar }\end{array}$ & $\begin{array}{l}\text { G: } \\
\text { Am: }\end{array}$ & $\begin{array}{l}\text { Good } \\
\text { Good; }\end{array}$ & ellowish gray \\
\hline & & $\begin{array}{l}\mathrm{R}: \\
\mathrm{Sp}:\end{array}$ & $\begin{array}{l}\text { Dark yellow } \\
\text { None }\end{array}$ \\
\hline Oatmeal agar & G: & $\begin{array}{l}\text { Good } \\
\text { Am: } \\
\text { R: } \\
\text { Sp: }\end{array}$ & $\begin{array}{l}\text { Good; Yellowish gray } \\
\text { Yellowish orange } \\
\text { None }\end{array}$ \\
\hline
\end{tabular}

G: growth, Am: aerial mycelium, R: reverse side of colony, Sp: soluble pigment.

Table 2. Physiological properties of strain QM16.

\begin{tabular}{ll}
\hline $\begin{array}{l}\text { Temperature for growth } \\
\text { Production of melanoid pigments } \\
\text { Tyrosine agar }\end{array}$ & $15 \sim 35^{\circ} \mathrm{C}$ \\
Peptone-yeast extract-iron agar & Negative \\
Tryptone-yeast extract agar & Negative \\
Hydrolysis of starch & Negative \\
Liquefaction of gelatin & Negative \\
Coagulation of milk & Negative \\
Peptonization of milk & Negative \\
Reduction of nitrate & Negative \\
Utilization of carbon source: & Negative \\
Utilized & \\
& L-arabinose, D-xylose, D-glucose, \\
Moderately utilized & D-fructose, inositol, L-rhamnose, \\
& raffinose, D-mannitol \\
\hline
\end{tabular}

taining $100 \mathrm{ml}$ of fermentation medium consisting of potato starch $1 \%$, glucose $1 \%$, glycerol $1 \%$, polypeptone $0.5 \%$, yeast extract $0.2 \%$, corn steep liquor $1 \%, \mathrm{NaCl}$ $0.1 \%$ and $\mathrm{CaCO}_{3} 0.32 \%$, the $\mathrm{pH}$ being adjusted to 7.4 before sterilization. The fermentation was carried out at $27^{\circ} \mathrm{C}$ for 5 days with shaking on a rotary shaker at 200 rpm.

\section{Isolation and Purification}

The isolation was guided by a bioassay (in vitro cytotoxicity against $\mathrm{P} 383$ cells).

The fermentation broth (1 liter) was centrifuged to give supernatant and mycelium cake. The mycelium cake was extracted with acetone ( 0.5 liter). The extract was filtered and concentrated in vacuo to an aqueous solution. The solution was mixed with the supernatant and 
Fig. 2. Isolation scheme of gilvusmycin.

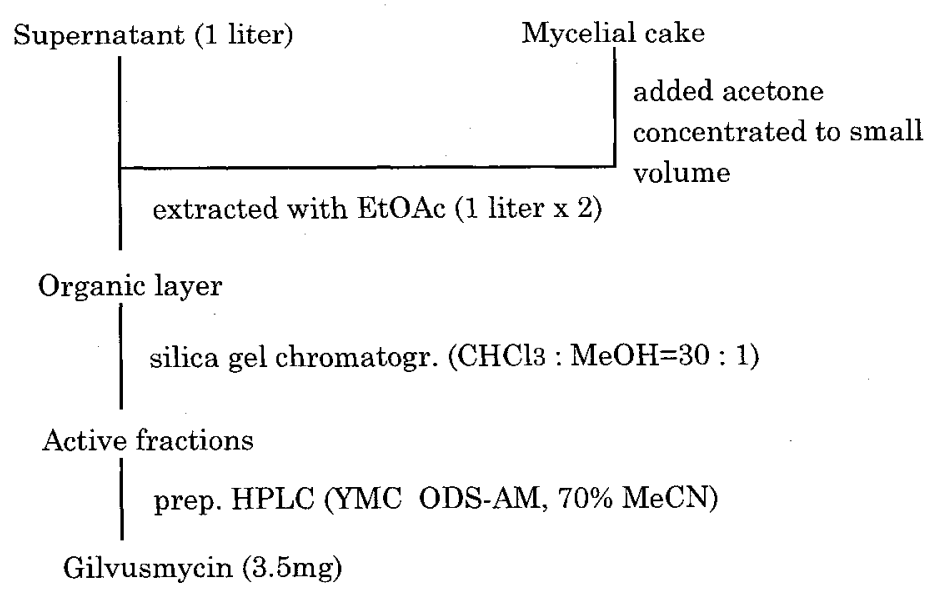

Table 3. Physicochemical properties of gilvusmycin.

\begin{tabular}{ll}
\hline Appearance & Yellow powder \\
$\mathrm{MP}$ & $160 \sim 162{ }^{\circ} \mathrm{C}(\mathrm{dec})$ \\
[a $]_{\mathrm{D}}^{20}$ & $+85^{\circ}(\mathrm{c} 0.1, \mathrm{DMF})$ \\
Molecular formula & $\mathrm{C}_{38} \mathrm{H}_{34} \mathrm{O}_{8} \mathrm{~N}_{6}$ \\
HRFAB-MS Calcd: & 703.2516 \\
$\quad$ Found: & $703.2515 \quad(\mathrm{M}+\mathrm{H})^{+}$ \\
$\mathrm{UV}$ I $_{\max }(\mathrm{e})(\mathrm{in} \mathrm{MeOH})$ & $276(27,500), 370(33,300)$ \\
$\mathrm{IR} \mathrm{n}(\mathrm{KBr}) \mathrm{cm}^{-1}$ & $3446,1660,1572,1522,1385$, \\
& $1306,1269,1132,588$ \\
\hline
\end{tabular}

extracted twice with 1 liter of ethyl acetate without adjusting $\mathrm{pH}$. After evaporation, the residue was applied to a silica gel column (Wakogel, C-200, $3 \times 30 \mathrm{~cm}$ ) which was developed with chloroform-methanol $(30: 1)$. The active eluate was concentrated to dryness, solubilized in DMSO and then subjected to preparative HPLC (YMC ODS-AM, i.d. $2 \mathrm{~cm} \times 25 \mathrm{~cm}, 70 \%$ aq $\mathrm{MeCN}$ ). The active fractions were concentrated to dryness to give a yellow powder of $\mathbf{1}(3.5 \mathrm{mg})$. The isolation scheme is shown in Fig. 2.

\section{Structural Elucidation}

The physico-chemical properties of 1 are summarized in Table 3. The molecular formula of $\mathbf{1}$ was established as $\mathrm{C}_{38} \mathrm{H}_{34} \mathrm{O}_{8} \mathrm{~N}_{6}$ on the basis of HRFAB-MS data. In the IR spectrum, 1 showed broad strong bands from 1630 to $1700 \mathrm{~cm}^{-1}$ suggesting the prerence of several carbonyl functions in $\mathbf{1}$. The ${ }^{1} \mathrm{H}$ NMR spectrum taken in DMSO- $d_{6}$ (Fig. 3) revealed the presence of cyclopropane-derived methylene resonance $\left(\delta_{\mathrm{H}} 1.42,1.98\right)$, two methyl resonances $\left(\delta_{\mathrm{H}} 2.00,2.30\right)$, six methylene resonances $\left(\delta_{\mathrm{H}} 3.25,3.31,4.25,4.32,4.45,4.64\right)$, two methoxy resonances $\left(\delta_{\mathrm{H}} 3.84,3.88\right)$, four olefinic methine resonances $\left(\delta_{\mathrm{H}} 6.42,6.86,7.04,7.11\right)$, two hydrogenbound phenolic hydroxyl resonances $\left(\delta_{\mathrm{H}} 11.00,12.20\right)$ and three imine resonances $\left(\delta_{\mathrm{H}} 11.36,11.38,11.41\right)$. The ${ }^{13} \mathrm{C}$ NMR spectrum demonstrated 38 signals which were assigned to four methyls, six methylenes, five methines and 23 quaternary carbons by DEPT experiment. The 
Fig. 3. $50 \mathrm{MHz}{ }^{1} \mathrm{H}$ NMR spectrum of gilvusmycin in DMSO- $d_{6}$.

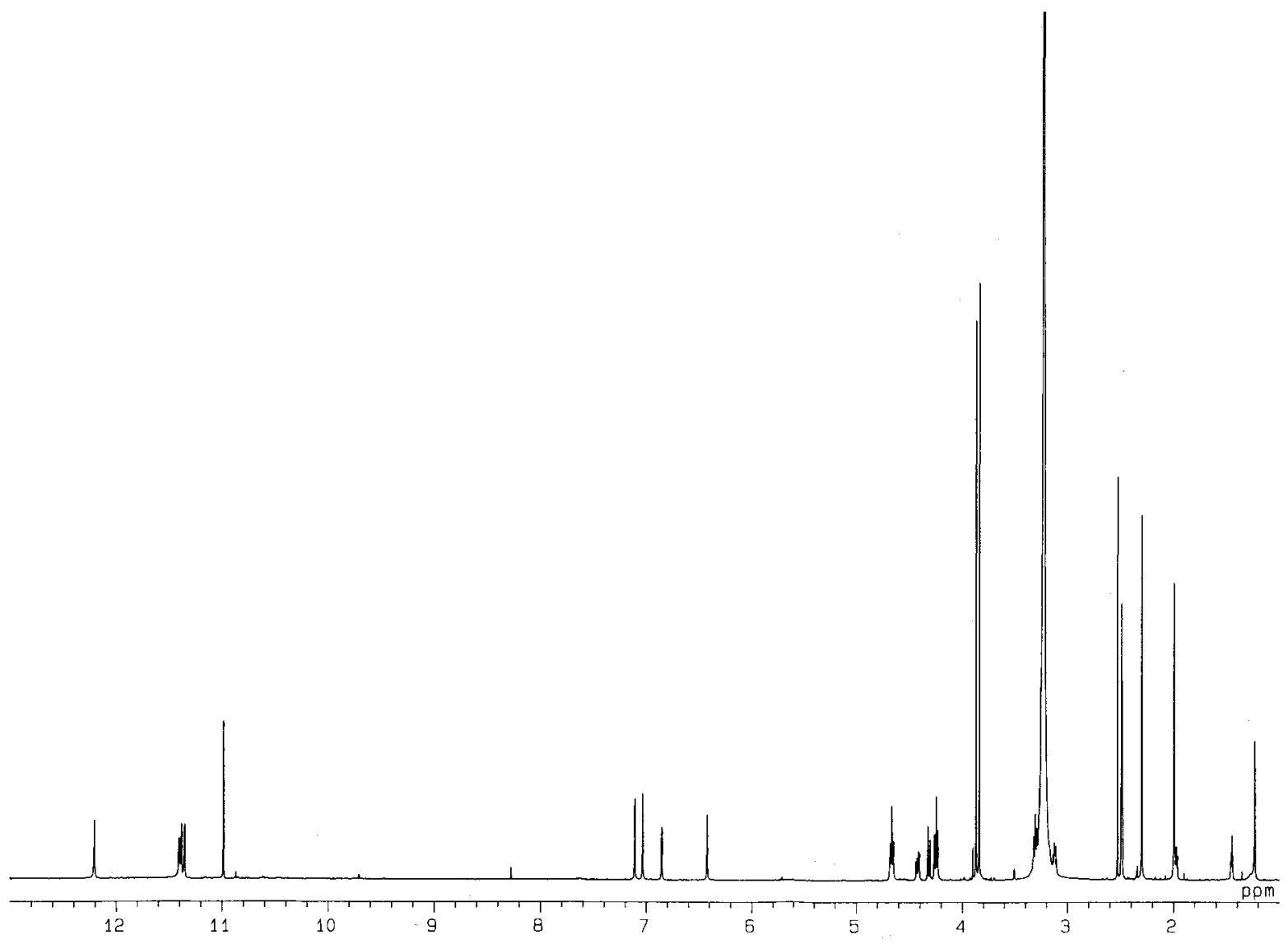

${ }^{1} \mathrm{H}$ and ${ }^{13} \mathrm{C}$ NMR spectral data for $\mathbf{1}$ are summarized in Table 4.

The characteristic UV spectrum of $\mathbf{1}$ suggested that $\mathbf{1}$ had considerable similarity to $\mathbf{2}^{3}$. Comparison of NMR spectral data of 1 and $\mathbf{2}^{\mathbf{4}}$ also supported it. Analyzing the difference, in ${ }^{1} \mathrm{H} \mathrm{NMR}, 1$ had an additional resonance of singlet methyl at $\delta_{\mathbf{H}} 2.30$, and in ${ }^{13} \mathrm{C}$ NMR, the resonance of carbamoyl group at $\delta_{\mathrm{C}} 157.5$ in 2 was absent in $\mathbf{1}$, in exchange of that, $\mathbf{1}$ had two resonances, one is of carbonyl carbon at $\delta_{\mathrm{C}} 169.3$ and the other is of singlet methyl at $\delta_{\mathrm{C}} 24.0$. The analysis above and the difference of molecular formula $\left(\mathrm{C}_{38} \mathrm{H}_{34} \mathrm{O}_{8} \mathrm{~N}_{6}: 1, \mathrm{C}_{37} \mathrm{H}_{33} \mathrm{O}_{8} \mathrm{~N}_{7}: 2\right)$ strongly suggested that carbamoyl group in 2 was exchanged to acetyl group in $\mathbf{1}$. The $\mathrm{HMBC}^{5)}$ experiments on 1 proved that the linkages of $\mathrm{C}-1 \sim \mathrm{C}-39$ in 2 were conserved in 1. Additionally, a long range coupling from 41- $\mathrm{CH}_{3}$ to $\mathrm{C}-40$ (carbonyl carbon) was also observed to support the existence of acetyl group in 1. Furthermore, $\mathrm{NOE}$ between $41-\mathrm{CH}_{3}$ and $38-\mathrm{CH}_{2}$ proved that the acetyl group was attached to the nitrogen at 39 . For all these findings, the total structure of $\mathbf{1}$ was deduced as shown in Fig. 1.

\section{Biological Activity}

1 was tested for its in vitro cytotoxicity. $\mathrm{IC}_{50}(\mu \mathrm{g} / \mathrm{ml})$ values against P388 (murine leukemia), K562 (human chronic myelogenous leukemia), A431 (human epidermoid carcinoma) and MKN28 (human gastric carcinoma) are shown in Table 5. Because of the outstanding cytotoxicity to P388, antitumor activity of $\mathbf{1}$ was assessed in P388-bearing mice and the results are shown in Table 6. 1 exhibited significant antitumor activity.

\section{Experimental}

General

Specific rotation was obtained on a Jasco DIP-140 
Table 4. $125 \mathrm{MHz}{ }^{13} \mathrm{C} \mathrm{NMR}$ and $500 \mathrm{MHz}{ }^{1} \mathrm{H}$ NMR spectral data of gilvusmycin (1) and CC-1065 (2) taken in DMSO- $d_{6}$.

\begin{tabular}{|c|c|c|c|}
\hline \multirow[b]{2}{*}{ Position } & \multicolumn{2}{|r|}{1} & \multirow{2}{*}{$\begin{array}{c}2 \\
\delta_{\mathrm{C}}\end{array}$} \\
\hline & $\delta_{C}$ & $\delta_{H}$ & \\
\hline $1-\mathrm{NH}$ & & \multicolumn{2}{|l|}{$11.41\left(\mathrm{~d}, 2,5^{\mathrm{b}}\right)$} \\
\hline 2 & $123.3 \mathrm{~d}$ & \multirow[t]{2}{*}{$6.86(\mathrm{~d}, 2.5)$} & 123.5 \\
\hline 3 & $112.8 \mathrm{~s}$ & & 113.0 \\
\hline $3 \mathrm{M}$ & $9.4 \mathrm{q}$ & \multirow[t]{4}{*}{$2.00(\mathrm{~s})$} & 9.5 \\
\hline 4 & $126.7 \mathrm{~s}$ & & 129.5 \\
\hline 5 & $128.8 \mathrm{~s}$ & & 157.5 \\
\hline 6 & $176.2 \mathrm{~s}$ & & 176.4 \\
\hline 7 & $110.4 \mathrm{~d}$ & \multirow[t]{3}{*}{$6.42(s)$} & 110.6 \\
\hline 8 & $160.5 \mathrm{~s}$ & & 160.7 \\
\hline 9 & $31.4 \mathrm{~s}$ & & 31.5 \\
\hline \multirow[t]{2}{*}{10} & \multirow[t]{2}{*}{$21.0 \mathrm{t}$} & $1.42(\mathrm{dd}, 4.4,4.4)$ & \multirow[t]{2}{*}{21.6} \\
\hline & & $1.98(\mathrm{dd}, 4.4,4.4)$ & \\
\hline 11 & $20.7 \mathrm{~d}$ & $3.12(\mathrm{ddd}, 4.4,4.4,5.0)$ & 20.9 \\
\hline \multirow[t]{2}{*}{12} & \multirow[t]{2}{*}{$54.5 \mathrm{t}$} & $4.32(\mathrm{~d}, 11.0)$ & \multirow[t]{2}{*}{49.4} \\
\hline & & $4.45(\mathrm{dd}, 5.0,11.0)$ & \\
\hline 14 & $161.2 \mathrm{~s}$ & & 161.2 \\
\hline $15-\mathrm{NH}$ & & \multirow[t]{2}{*}{$11.38(\mathrm{~d}, 1.8)$} & \\
\hline 16 & $129.6^{\mathrm{c}} \mathrm{s}$ & & 127.2 \\
\hline 17 & $105.7 \mathrm{~d}$ & \multirow[t]{4}{*}{$7.04(\mathrm{~d}, 1.8)$} & 105.9 \\
\hline 18 & $117.6 \mathrm{~s}$ & & 117.3 \\
\hline 19 & $130.3^{\mathrm{c}} \mathrm{s}$ & & 130.4 \\
\hline 20 & $133.0 \mathrm{~s}$ & & \\
\hline $20 \mathrm{M}$ & $60.1 \mathrm{q}$ & $3.88(\mathrm{~s})$ & 60.0 \\
\hline 21 & $138.2 \mathrm{~s}$ & \multirow[t]{3}{*}{$11.00(\mathrm{OH})$} & 132.4 \\
\hline 22 & $127.2 \mathrm{~s}$ & & 128.9 \\
\hline 23 & $120.6 \mathrm{~s}$ & & 121.3 \\
\hline 24 & $27.4 \mathrm{t}$ & $3.31(\mathrm{dd}, 8.0,9.5)$ & 26.6 \\
\hline 25 & $53.1 \mathrm{t}$ & \multirow[t]{2}{*}{$4.64(\mathrm{t}, 8.0)$} & 53.3 \\
\hline 27 & $160.0 \mathrm{~s}$ & & 160.2 \\
\hline 28-NH & & \multicolumn{2}{|l|}{$11.36(\mathrm{~d}, 2.5)$} \\
\hline 29 & $130.3^{\mathrm{c}} \mathrm{s}$ & \multirow{5}{*}{$7.11(\mathrm{~d}, 2.5)$} & 127.5 \\
\hline 30 & $106.4 \mathrm{~d}$ & & 106.3 \\
\hline 31 & $117.2 \mathrm{~s}$ & & 117.7 \\
\hline 32 & $130.6^{\mathrm{c}} \mathrm{s}$ & & 130.7 \\
\hline 33 & $132.4 \mathrm{~s}$ & & \\
\hline $33 \mathrm{M}$ & $59.9 \mathrm{q}$ & $3.84(\mathrm{~s})$ & 60.3 \\
\hline 34 & $138.2 \mathrm{~s}$ & \multirow[t]{3}{*}{$12.20(\mathrm{OH})$} & 133.1 \\
\hline 35 & $127.0 \mathrm{~s}$ & & 129.1 \\
\hline 36 & $121.1 \mathrm{~s}$ & & 118.2 \\
\hline 37 & $26.4 \mathrm{t}$ & $3.25^{\mathrm{d}}$ & 27.6 \\
\hline 38 & $50.8 \mathrm{t}$ & \multirow[t]{2}{*}{$4.25(t, 8.0)$} & 54.8 \\
\hline 40 & $169.3 \mathrm{~s}$ & & 157.5 \\
\hline 41 & $24.0 \mathrm{q}$ & $2.30(\mathrm{~s})$ & \\
\hline
\end{tabular}

a Cited from the data by Martin et $a l^{4}$.

b Coupling constants in $J=\mathrm{Hz}$.

c The assignments may be interchanged.

d Resonance in one-dimentional spectra obscured by overlapping signals. 
spectropolarimeter. Mass spectra were measured on a JEOL JMS-SX102A in the FAB mode using glycerol matrix. UV and IR spectra were recorded on a Hitachi U-3200 spectrophotometer and a Jasco A-3 spectrophotometer, respectively. NMR spectra were obtained on a JEOL JNM- $\alpha 500$ spectrophotometer with ${ }^{1} \mathrm{H}$ NMR at $500 \mathrm{MHz}$ and ${ }^{13} \mathrm{C}$ NMR at $125 \mathrm{MHz}$. Chemical shifts are given in ppm using TMS as internal standard.
Table 5. In vitro cytotoxicity of gilvusmycin.

\begin{tabular}{ll}
\hline Cell line & $\mathrm{IC}_{50}(\mathrm{ng} / \mathrm{ml})$ \\
\hline P388 & 0.08 \\
K562 & 0.86 \\
A431 & 0.72 \\
MKN28 & 0.75 \\
\hline
\end{tabular}

Table 6. In vivo antitumor activity of gilvusmycin against P388 murine leukemia.

\begin{tabular}{ccc}
\hline Dose $(\mathrm{mg} / \mathrm{kg} /$ day $)$ & MST (days) & T/C $(\%)$ \\
\hline 0 (Control) & $11.0 \pm 0.9$ & 100 \\
0.11 & $9.8 \pm 3.3$ & 89.1 \\
0.037 & $14.4 \pm 3.1$ & 130.9 \\
0.0123 & $12.2 \pm 0.5$ & 110.9 \\
\hline
\end{tabular}

MST: Mean Survival Time.

P388 was implanted ip into $\mathrm{CDF}_{1}$ mice $\left(1.0 \times 10^{6}\right.$ cells/mouse $)$ on the day 0 , then /gilvusmycin was given ip on the days 1,5 and 9 .

\section{References}

1) Reynolds, V. L.; J. P. McGovren \& L. H. Hurley: The chemistry, mechanism of action and biological properties of CC-1065, a potent antitumor antibiotic. J. Antibiotics 39: 319 334, 1986

2) Shirling, E. B. \& D. Gottlieb: Methods for characterization of Streptomyces species. Int. J. Syst. Bacteriol. 16: 313 340, 1966

3) Frolova, V. I.; A. D. Kuzovkov, A. I. Chernyshev, M. M. TAIG \& L. P. IVAnitskaia: Identification of the antibiotic formed by a Streptomyces canulus $106 / 78$ culture with antibiotic CC-1065. Antibiotiki 27: 483 487, 1982

4) Martin, D. G.; C. Biles, S. A. Gerpheide, L. J. Hanka, W. C. Krueger, J. P. McGovren, S. A. Mizsak, G. L. Neil, J. C. Stewart \& J. Visser: CC-1065 (NSC 298223), a potent new antitumor agent improved production and isolation, characterization and antitumor activity. J. Antibiotics 34: $1119 \sim 1125$, 1981

5) BAX, A. \& M. F. Summers: ${ }^{1} \mathrm{H}$ and ${ }^{13} \mathrm{C}$ assignments from sensitivity-enhanced detection of heteronuclear multiple-bond connectivity by $2 \mathrm{D}$ multiple quantum NMR. J. Am. Chem. Soc. 108: 2093 2094, 1986 